放射線外部照射治療において，照射野内に整形外科治 療用ステンレス鋼を含めて照射しなければならない場合 がしばしば起こる．今回，利用頻度の高い金属 SUS316 について線量分布に与える影響を測定した。

〔方法〕アクリルファントムを用いて金属の前後の線 量を shallow 型電離箱により詳細に測定し，金属のない 場合の PDD と比較した。

〔結果〕10MV-X 線では, ステンレスからの後方散乱 の影響で境界面の前方 $1 \mathrm{~cm}$ より線量増加が起こり, 境 界面では約 $128 \%$ にまで増加した。また透過直後の線量は ステンレス厚 $1.5 \mathrm{~mm} \sim 6 \mathrm{~mm}$ で8.4〜14\%の低下であり， $4 \mathrm{~mm}$ 後方で peak を持った後は1.3〜9.4\%の減少とな った.

\section{Dental metalの線量分布に及ばす影㫶について} ${ }^{60} \mathrm{Co} \gamma$ 線一

岡山大学医学部附属病院

○稲村圭司・三村誠一・田原誠司

若狭弘之・江草具視・三上泰隆

岡山大学医療技術短期大学部

中桐義忠・杉田勝彦

〔目的〕第46回総会において, 10MV-X 線外部照射時 に dental metal が線量分布に及浔す影響について報告 した. 今回，われわれはさらに頭頝部領域の治療でよく 使用される ${ }^{60} \mathrm{Co} \gamma$ 線について同様な実験を行い検討し た。

〔結果〕実験した0.3 mm〜1.5 mm 厚の dental metalにおいては, metal 前方 $2 \mathrm{~mm}$ より後方散乱線に よる線量増加が起こり，境界部前面で $150 \%$ に達した。ま た，境界部後面で吸収のため，線量は20〜25\%減少する が, $2 \mathrm{~mm}$ 後方からは $1 \sim 7 \%$ の減少となった. ${ }^{60} \mathrm{Co}$ 外部 照射においては, $2 \mathrm{~mm}$ 程度の薄いマウスピースを用い ることで，口内炎を軽減することが可能と思われる.

\section{1. 電子線不整形照射野の検討}

\section{川崎医科大学附属病院}

○長瀬尚巳・沼口健治・古城 剛 成廣直正・安井宏江・赤澤裕二 日地啓夫

三菱 ML-15MDX リニアックの非密着型電子線アプ リケータを使用して, 皮膚面から $17 \mathrm{~cm}$ 離れた位置で不 整形照射野の照射野トリミングを行えるように工夫した。 トリミング材として $0.5 \mathrm{~cm}$ 厚鉛板を使用した.この方法 の深部電離量曲線への影響は認められなかった。また beam profile および線量分布への影響も臨床上無視し得 る程度であった。吸収線量への影響は遮蔽部分が多くな
るほど等価照射野のアプリケー夕に対し大となり，電子 線エネルギーが低い場合のほうがより顕著となった。こ のトリミング法は電子線エネルギー, 線量分布, 鉛板か らの散乱放射線などの影響がなく，光照射野により容易 にトリミング可能であり有用な方法であると考えられる.

\section{2. 乳房温存革法における線贯評価点の検討}

川崎医科大学附属病院

○安井宏江・沼口健治・長瀬尚巳 古城 剛・成廣直正・赤澤裕二 日地啓夫

乳房温存術後の放射線治療で用いられる, 接線照射の 線量分布, 線量評価点および monitor unit 計算について 乳房ファントムを用いて検討した。多分割コリメータを 利用した $4 \mathrm{MVX}$ 線 half - field 法 (wedgeなし) の Modulexによる線量分布, 均一性とも wedge 使用の非 対向照射法に匹敵し，フィルム法による測定値とよく一 致した.CT 情報をもとに Modulexにより評価点の線量 を求めることで monitor unit 計算も正確に行える。また 照準の容易さ，照射の再現性とも良好であり，鉛ブロッ クを用いた half-field 法と異なり, 健側乳房の被曝も他 の照射法と変わらず有用な照射法と思われる. 今後体軸 方向への三次元的な配慮が必要と考えられる.

63. パイパス術適用による食道腔内照射法の検討

高知医科大学附属病院

横田典和・伊東賢二・森尾一夫

田和 誠・遠山坦彦・小川恭弘

バイパス術を適用した食道に対する広範囲な高線量率 腔内照射に際し, 線源送戻を繰り返すことによる線量付 加について検討した。

腔内照射での線量評価は Modulex 計算値にて行うが, 実際の照射方法を模した時, 実測值に比べ Modulex 計 算值は線源送戻による線量付加分を考慮していないため $6 \%$ 程度過少評価であった。この線源送戻による線量付 加分を線源停止時間に換算し, Modulex での計算に照射 時間の増加として補正を行うと実測值に近い結果となっ た.つまり照射範囲が広範用で線源送戻を繰り返さなけ ればならない時, 線源移動中の線量付加を考慮し補正が 必要と考える。

\section{座長集約}

このセッションは治療上の問題点や照射法の改良につ いて基礎実験を行い検討した 5 題の報告である。

演題59と60は体内金属に対しての線量変化の分析であ る.実験状態はともに金属の前後方向についての測定で ある．今後金属を中心として側方まで含めた線量分布に 